Argonne National Laboratory

9700 South Cass Avenue, Argonne, Illinois 60439

\title{
DERIVATION OF BERYLLIUM GUIDELINES \\ FOR USE IN ESTABLISHING CLEANUP \\ LEVELS AT THE PEEK STREET AND \\ SACANDAGA SITES, NEW YORK
}

by

H.M. Hartmann, H.I. Avci, and J.D. Ditmars

Environmental Assessment and Information Sciences Division

February 1992

work supported by

U.S. Department of Energy

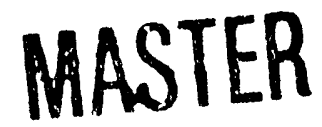




\section{CONTENTS}

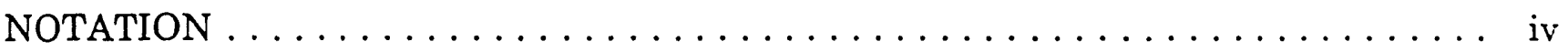

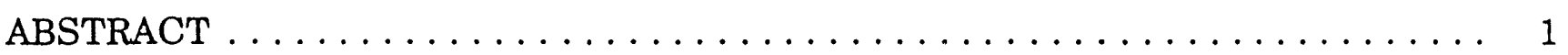

1 INTRODUCTION $\ldots \ldots \ldots \ldots \ldots \ldots \ldots \ldots \ldots \ldots \ldots \ldots \ldots \ldots \ldots \ldots \ldots \ldots \ldots$

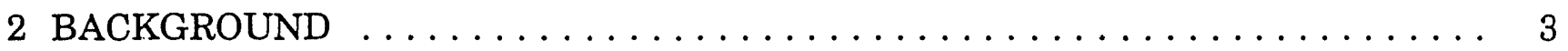

3 GUIDELINE LEVELS FOR BERYLLIUM IN SOIL $\ldots \ldots \ldots \ldots \ldots \ldots \ldots$

4 GUIDELINE LEVELS FOR BERYLLIUM ON INDOOR SURFACES $\ldots \ldots \ldots \ldots 6$

5 GUIDELINE LEVELS FOR BERYLLIUM IN AiR $\ldots \ldots \ldots \ldots \ldots \ldots \ldots$

6 DISCUSSION AND SUMMARY $\ldots \ldots \ldots \ldots \ldots \ldots \ldots \ldots \ldots \ldots \ldots \ldots \ldots \ldots \ldots$

6.1 Beryllium in Soil . . . . . . . . . . . . . . . 8

6.2 Beryllium on Indoor Surfaces $\ldots \ldots \ldots \ldots \ldots \ldots \ldots \ldots \ldots \ldots \ldots$

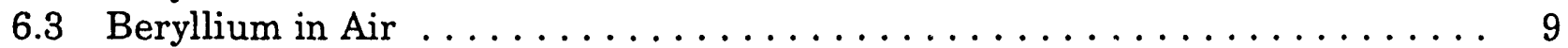

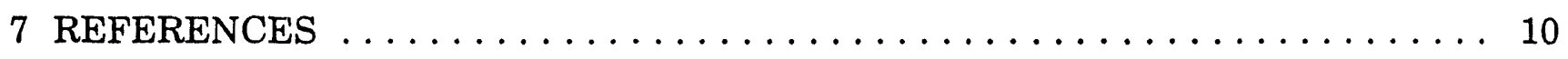

APPENDIX: Equations and Parameter Values $\ldots \ldots \ldots \ldots \ldots \ldots \ldots \ldots$ 


\section{NOTATION}

The following is a list of the acronyms, initialisms, and abbreviations (including units of measure) used in this document.

\section{ACRONYMS, INITIALISMS, AND ABBREVIATIONS}

AEC Atomic Energy Commission

DOE U.S. Department of Energy

EPA U.S. Environmental Protection Agency

IRIS Integrated Risk Information System

NPL National Priorities List

ORNL Oak Ridge National Laboratory

OSHA Occupational Safety and Health Administration

PEL permissible exposure limit

RfD reference dose

\section{UNITS OF MEASURE}

${ }^{\circ} \mathrm{C}$ degrees Celsius

d $\operatorname{day}(\mathrm{s})$

$\mathrm{ft}^{2} \quad$ square foot (feet)

g $\operatorname{gram}(\mathrm{s})$

h hour(s)

kg kilogram(s)

$\mu \mathrm{g}$ microgram(s)

$\mathrm{m}^{2} \quad$ square meter(s)

$\mathrm{m}^{3} \quad$ cubic meter(s)

$\mathrm{mg}$ milligram(s)

yr year(s) 


\title{
DERIVATION OF BERYLLIUM GUIDELINES FOR USE IN ESTABLISHING CLEANUP \\ LEVELS AT THE PEEK STREET AND SACANDAGA SITES, NEW YORK
}

by

H.M. Hartmann, H.I. Avci, and J.D. Ditmars

\begin{abstract}
Guideline levels are derived for beryllium in soil and on indoor surfaces at the Peek Street and Sacandaga sites in the state of New York. On the basis of highly conservative assumptions, the soil beryllium concentration that corresponds to a $10^{-4}$ carcinogenic risk level is estimated to be $13 \mathrm{mg} / \mathrm{kg}$ at both sites. Calculations indicate that the proposed U.S. Department oi . Tnergy guideline of $2 \mu \mathrm{g} / \mathrm{ft}^{2}$ for beryllium in dust on indoor surfaces wculd be sufficiently protective of human health. For occupational protection of workers during cleanup operacions, Office of Safety and Health Administration standards for berylliun $\iota$ are referenced and restated.
\end{abstract}

\section{INTRODUCTION}

The Peek Street Industrial Facility, located at 425 Peek Street, Schenectady, New York, was operated by the General Electric Company for the Atomic Energy Commission (AEC) between 1947 and 1955. A variety of operations using radioactive materials were conducted at the site; primary activities, however, were the design of an intermediate breeder reactor and the development of a chemical process for the recovery of uranium and plutonium from spent reactor fuel. Nonradioactive beryllium metal was machined on the site for breeder reactor application. The 4.5-acre site was decommissioned and released in October 1955.

The Sacandaga site, located on Sacandaga Road, Glenville, New York, was operated by the General Electric Company for the AEC between 1947 and 1951. Originally used for the study and development of radar during World War II, the facilities later housed operations involving physics studies and sodium technology development in support of breeder reactor design and other AEC programs. The equipment was dismantled and removed in the early 1950s. Currently one building and a concrete bunker at the east end of the property are the only aboveground structures still standing.

Surveys conducted by Oak Ridge National Laboratory (ORNL) have shown localized areas at both the Peek Street and Sacandaga sites where concentrations of beryllium are 
above background levels. The total soil area containing elevated beryllium is about $5 \mathrm{~m}^{2}$ at the Peek Street site and is contained within the bunker at the Sacandaga site. At the Peek Street site, the soil beryllium levels were found to range from 0.56 to $340 \mathrm{mg} / \mathrm{kg}$ (Foley et al. 1992a). At the Sacandaga site, beryllium levels in soil, gravel, and stone within the concrete bunker ranged from 1.4 to $880 \mathrm{mg} / \mathrm{kg}$ (Foley et al. 1992b). For comparison, various geochemical surveys have reported background levels of beryllium in soil ranging from 0.6 to $7 \mathrm{mg} / \mathrm{kg}$ (Shacklette and Boerngen 1984).

In addition, the beryllium concentrations in dust on some horizontal surfaces inside the industrial building of the Peek Street site have been found to range from 0.42 to $61 \mu \mathrm{g} / \mathrm{g}$. One sample, consisting of chips from one of the walls inside the building had a beryllium concentration of $330 \mu \mathrm{g} / \mathrm{g}$. The remaining wall and floor samples had concentrations ranging from less than 1 to $6.1 \mu \mathrm{g} / \mathrm{g}$.

This report presents the health-risk based guideline levels for beryllium in soil and on indoor surfaces. References are provided for guideline values for beryllium in air. These guidelines are based on possible exposure through inhalation or ingestion, which are the primary exposure pathways of concern. Significant absorption of beryllium or its compounds through intact skin is unlikely because of its chemical properties (ATSDR 1988). The guidelines are derived to ensure that unrestricted use (e.g., industrial or residential) of the Peek Street and Sacandaga sites will not result in any significant exposure to beryllium for individuals who may frequent these sites, for the general public, or for the environment. Guideline level derivation for soils is based on hypothetical future residential use of the sites. This use would result in the highest exposure levels and would therefore yield the most protective cleanup levels. Guideline level derivation for indoor surfaces is based on future commercial use of the site structures. The guideline levels for indoor air are provided for occupational exposure during cleanup of the building at the Peek Street site. For the general public, no air concentration guidelines are needed because the source of airborne beryllium is what is in the soil or on indoor surfaces, and the soil guidelines and indoor surface contamination guidelines are, in part, based on acceptable air concentrations. 


\section{BACKGROUND}

Known toxic effects of beryllium are due to the inhalation of beryllium and beryllium compounds in the workplace, which results in severe irritation and inflammation of the skin and lungs at high exposure levels of approximately $100 \mu \mathrm{g} / \mathrm{m}^{3}$ (DOE 1991). Chronic inhalation of lower levels of beryllium and beryllium compounds can result in chronic beryllium disease, a condition typified by labored breathing, weight loss, and chest pain, among other symptoms (DOE 1991). Beryllium inhalation has also been associated with lung cancer in several epidemiologic studies, and beryllium is considered to be a probable human carcinogen by the U.S. Environmental Protection Agency (EPA). The only health effect that has been observed as the result of oral exposure to beryllium is an elevated number of tumors in rats given beryllium in drinking water.

The reference levels for possible toxic effects of beryllium used in this document are the EPA-derived oral reference dose (RfD) and carcinogenic slope factors. The RfD is defined as "an estimate of a daily exposure level for the human population, including sensitive subpopulations, that is likely to be without an appreciable risk of deleterious effects during a lifetime" (EPA 1989). If the sum of the ratio of the intake to the RfD value (i.e., hazard index) for a contaminant at a site is less than 1, this indicates that noncarcinogenic toxicity is unlikely. The slope factor is defined as a "plausible upper-bound estimate of the probability of a response (i.e., cancer) per unit intake of a chemical over a lifetime" (EPA 1989). The carcinogenic slope factor multiplied by the intake level yields a lifetime cancer risk estimate. Both RfD and slope factor values are specific to either ingestion or inhalation exposure.

The RfD and slope factor toxicity reference levels are appropriate for hypothesized future residential use of a site because they take into account chronic daily exposure and sensitive human subpopulations; occupational reference levels based on healthy adult males do not take these factors into account. Currently no inhalation RfD is available for beryllium. To evaluate noncarcinogenic effects of inhalation of beryllium, the permissible exposure limit (PEL) for occupational inhalation currently enforced by the Occupational Safety and Health Administration (OSHA) (U.S. Departrsent of Labor 1991) can be modified to account for chronic daily exposure and sensitive human subpopulations. This modified inhalation PEL is used in this report to derive air and soil reference levels for comparison with those derived by using the inhalation slope factor for beryllium. The modified PEL and the inhalation slope factor are also used for derivation of reference levels for indoor surfaces. Additional assumptions used for duration of residency or employment at a site and chronic daily intake levels are based on values currently recommended by the EPA (1991a).

The oral RfD value and oral and inhalation slope factors for beryllium are given in the EPA Integrated Risk Information System (IRIS) (EPA 1991b). The oral RfD for beryllium is $0.005 \mathrm{mg} / \mathrm{kg} / \mathrm{d}$, based on no adverse effects in a chronic study conducted using rats. The oral slope factor based on tumors produced in rats is $4.3(\mathrm{mg} / \mathrm{kg} / \mathrm{d})^{-1}$. The inhalation slope factor based on increased incidence of lung cancer among beryllium workers is $8.4(\mathrm{mg} / \mathrm{kg} / \mathrm{d})^{-1}$. 
For known or suspected carcinogens, slope factors can be used to calculate the carcinogenic risk associated with specific exposure levels. Exposure levels corresponding to risks in the range of $10^{-6}$ to $10^{-4}$ are considered acceptable for the general public at sites that are on the National Priorities List (NPL) (EPA 1990). This range will be considered the target risk range for the Peek Street and Sacandaga sites.

The permissible 8-hour time-weighted average beryllium air concentration for occupational exposure is $2 \mu \mathrm{g} / \mathrm{m}^{3}$ (U.S. Department of Labor 1991). This occupational standard can be converted to a chronic exposure level for comparison with the EPA-Herived values given above. To convert to a chronic exposure level, it is assumed that a worker is exposed to $2 \mu \mathrm{g} / \mathrm{m}^{3}$ of beryllium in air, 8 hours per day, 250 days per year, and has an inhalation rate of $0.83 \mathrm{~m}^{3} / \mathrm{h}$ (EPA 1991a). Use of these assumptions results in an annual exposure limit of $3,320 \mu \mathrm{g} / \mathrm{yr}$. This same annual exposure limit of $3,320 \mu \mathrm{g} / \mathrm{yr}$ equates to a chronic exposure level of $1.3 \times 10^{-4} \mathrm{mg} / \mathrm{kg} / \mathrm{d}$ for a $70-\mathrm{kg}$ person over a year (see Appendix). The EPA uses 10-fold uncertainty factors to account for sensitive human subpopulations in the derivation of reference doses (EPA 1989). Following this precedent results in a modified inhalation reference value of $1.3 \times 10^{-5} \mathrm{mg} / \mathrm{kg} / \mathrm{d}$ for the general public. Assuming that the general public is exposed 24 hours per day, 365 days per year, and a $70-\mathrm{kg}$ adult inhales air at a rate of $20 \mathrm{~m}^{3} / \mathrm{d}$, the average air concentration of beryllium allowable for the general public is calculated to be $0.045 \mu \mathrm{g} / \mathrm{m}^{3}$.

The soil concentrations corresponding to each of the above reference values (i.e., oral RfD, oral and inhalation slope factors, and the modified PEL value) are given in Section 3. The indoor surface concentrations corresponding to the modified PEL value and the inhalation slope factor are presented in Section 4, and guideline levels for beryllium in air are presented in Section 5. See the Appendix for the specific equations used to calculate each reference level. 


\section{GUIDELINE LEVELS FOR BERYLLIUM IN SOIL}

A possible route of human exposure to beryllium in soil is incidental soil ingestion. Reference values applicable to the oral route of exposure are the oral RfD and the oral slope factor. Assuming a 30-year residency at a site (including 6 years as a child) and incidental soil ingestion rates of $100 \mathrm{mg} / \mathrm{d}$ as an adult and $200 \mathrm{mg} / \mathrm{d}$ as a child (EPA 1989; EPA 1991a), the following soil concentrations correspond to the noncarcinogenic reference effect level (i.e., hazard index equal to 1 ) and the carcinogenic risks of $10^{-4}$ and $10^{-6}$, respectively (numbers are rounded to two significant figures):

$$
\begin{array}{ll}
\text { noncarcinogenic reference effect level } & 1,400 \mathrm{mg} / \mathrm{kg} \\
10^{-4} \text { carcinogenic risk level } & 15 \mathrm{mg} / \mathrm{kg} \\
10^{-6} \text { carcinogenic risk level } & 0.15 \mathrm{mg} / \mathrm{kg}
\end{array}
$$

Another possible route of human exposure to soil beryllium in a residential setting is ingestion of produce grown in beryllium-contaminated soil. However, the uptake of beryllium by plants is very low, with an estimated soil-to-plant transfer coefficient of 0.00042 ( $\mathrm{Ng}$ et al. 1968). In addition, because fruits do not take up significant quantities of metals, only vegetables are of concern (EPA 1991a). By using the above transfer coefficient and assuming vegetable consumption of $200 \mathrm{~g} / \mathrm{d}, 40 \%$ of which is homegrown produce, and 30 -year residency at a site (EPA 1991a), the corresponding soil levels are as follows:

$$
\begin{array}{ll}
\text { noncarcinogenic reference effect level } & 11,000 \mathrm{mg} / \mathrm{kg} \\
10^{-4} \text { carcinogenic risk level } & 120 \mathrm{mg} / \mathrm{kg} \\
10^{-6} \text { carcinogenic risk level } & 1.2 \mathrm{mg} / \mathrm{kg}
\end{array}
$$

Finally, exposure from soil may also occur via inhalation of soil-derived dust particles. In urban environments, the upper bounds of dust suspension have been estimated at $150 \mu \mathrm{g} / \mathrm{m}^{3}$ air, $50 \%$ of this dust is of respirable size (Paustenbach 1989). Assuming that all suspended dust is derived from contaminated soil, reference levels for beryllium in soil can be calculated on the basis of future residential land use assumptions and either the modified PEL reference level of $1.3 \times 10^{-5}$ (for noncarcinogenic effecis) or the EPA inhalation slope factor. The soil levels corresponding to these reference levels are as follows:

$$
\begin{array}{ll}
\text { noncarcinogenic reference effect level } & 640 \mathrm{mg} / \mathrm{kg} \\
10^{-4} \text { carcinogenic risk level } & 1,400 \mathrm{mg} / \mathrm{kg} \\
10^{-6} \text { carcinogenic risk level } & 14 \mathrm{mg} / \mathrm{kg}
\end{array}
$$




\section{GUIDELINE LEVELS FOR BERYLLIUM ON INDOOR SURFACES}

The receptor with the highest potential exposure in commercial buildings is likely to be an employee spending approximately 40 hours per week in the building. The potential exposure route of greatest concern for beryllium on indoor surfaces in commercial areas is inhalation of resuspended particulates. Although incidental ingestion and dermal contact with contaminants are also possible exposure routes, it is expected that good worker practices (e.g., no eating or smoking in work areas), combined with the fact that beryllium surface contamination exists primarily on overhead beams near the ceiling, should make exposure via these routes much less than that via inhalation.

If the concentration of beryllium in dust on indoor surfaces is known, an indoor surface level based on the inhalation slope factor or the modified PEL can be calculated in a manner similar to that given above for calculating soil reference levels for the inhalation of resuspended particulates exposure route. However, the dust concentration in air within buildings used for commercial purposes is assumed to be higher than that in ambient outdoor air; for these calculations, an indoor air dust concentration of $2 \mathrm{mg} / \mathrm{m}^{3}$ was assumed. In addition, exposure duration variables for an employee rather than a resident were incorporated (EPA 1991a). For example, the length of exposure was assumed to be 8 hours per day, 250 days per year, for 25 years. The beryllium levels in dust on indoor surfaces that correspond to the modified PEL (i.e., $0.045 \mu \mathrm{g} / \mathrm{m}^{3}$ ) and the inhalation slope factor are as follows:

noncarcinogenic reference effect level

$10^{-4}$ carcinogenic risk level

$10^{-6}$ carcinogenic risk level
$200 \mu \mathrm{g} / \mathrm{g}$

$510 \mu \mathrm{g} / \mathrm{g}$

$5.1 \mu \mathrm{g} / \mathrm{g}$ 


\section{GUIDELINE LEVELS FOR BERYLLIUM IN AIR}

The provisions of OSHA do not normally apply to working conditions at U.S. Department of Energy (DOE) facilities because DOE exercises statutory authority to prescribe and enforce safety and health standards at its facilities. The DOE exercises this authority on the basis of an agreement between the Secreiary of Energy and OSHA. However, in the absence of an established DOE industrial hygiene standard for beryllium, it is assumed that the OSHA occupational protection standard for beryllium could be used during the cleanup of the industrial building at the Peek Street site. The OSHA standards for beryllium are $2 \mu \mathrm{g} / \mathrm{m}^{3}$, 8-hour time-weighted aveiage; $5 \mu \mathrm{g} / \mathrm{m}^{3}$, acceptable ceiling concentration; and $25 \mu \mathrm{g} / \mathrm{m}^{3}$, maximum peak above the acceptable ceiling concentration for an 8-hour shift (U.S. Department of Labor 1991). 


\section{DISCUSSION AND SUMMARY}

\subsection{BERYLLIUM IN SOIL}

On the basis of the above discussion, the exposure route of greatest concern with respect to beryllium in soil is incidental ingestion, and the possible carcinogenic action of beryllium is the most sensitive health effect (i.e., the effect resulting from the lowest exposure level). For the incidental soil ingestion route, soil beryllium levels of 0.15 and $1.5 \mathrm{mg} / \mathrm{kg}$ correspond to carcinogenic risks of $10^{-6}$ and $10^{-5}$, respectively. A soil beryllium level of $15 \mathrm{mg} / \mathrm{kg}$ corresponds to a carcinogenic risk of $10^{-4}$. However, if all exposure routes are considered collectively (i.e., incidental soil ingestion, produce ingestion, and inhalation of soilderived particulates) the soil beryllium level that corresponds to a carcinogenic risk of $10^{-4}$ would be about $13 \mathrm{mg} / \mathrm{kg}$.

The above concentrations have been derived on the basis of highly conservative assumptions. For example, per EPA (1991a) guidance, incidental soil ingestion is assumed to occur 350 days per year. However, soil ingestion is highly unlikely on days of the year during which the ground is frozen or snow covered. In addition, the estimates of daily soil ingestion used in the risk calculations are values recommended by the EPA for sites with the potential for residential use. At the Peek Street and Sacandaga sites, the areas of elevated soil beryllium are highly localized, making it unlikely that a receptor would ingest the entire projected daily amount of soil (i.e., 100 or $200 \mathrm{mg}$ ) from an area of elevated beryllium concentration.

The target risk range for NPL sites set by the EPA is $10^{-6}$ to $10^{-4}$ for all residual contaminants remaining at a site after cleanup. Therefore, in addition to the site-specific considerations discussed above, the risks associated with other contaminants would also need to be considered to establish a cleanup level for any single contaminant, so that the overall risk associated with residual contamination would not exceed $10^{-4}$.

Practical considerations could also influence the final cleanup criteria adopted for a site. For example, concentrations of beryllium in the range of 5 to $15.3 \mathrm{mg} / \mathrm{kg}$ have been reported to be associated with coal ash (EPA 1987). Because coal ash is found extensively at the Peek Street and Sacandaga sites from sources believed to be unrelated to past site operations (Foley et al. 1992a, 1992b), it may be impract: $n$ al to clean up the sites to beryllium levels less than those present in coal ash.

\subsection{BERYLLIUM ON INDOOR SURFACES}

The DOE currently has proposed a housekeeping guideline of $2 \mu \mathrm{g}$ beryllium per square foot of surface area (DOE 1991). At the Peek Street site, this would result in a beryllium concentration in dust of less than $2 \mu \mathrm{g} / \mathrm{g}$ (Foley et al. 1992a), which is less than the level corresponding to a $10^{-6}$ carcinogenic risk (i.e., $5.1 \mathrm{\mu g} / \mathrm{g}$ ). Therefore, the proposed DOE 
housekeeping guideline is more than sufficient to reciuce health risks from beryllium on indoor surfaces to below acceptable risk-based guideline levels.

\subsection{BERYLLIUM IN AIR}

The OSHA occupational protection standards for beryllium could be used for cleanup of the industrial building at the Peek Street site. In terms of air concentrations, these standards are $2 \mu \mathrm{g} / \mathrm{m}^{3}$, 8-hour time-weighted average; $5 \mu \mathrm{g} / \mathrm{m}^{3}$, acceptable ceiling concentration; and $25 \mu \mathrm{g} / \mathrm{m}^{3}$, maximum peak above the acceptable ceiling concentration for an 8-hour shift. (U.S. Department of Labor 1991) 


\section{REFERENCES}

Agency for Toxic Substances and Disease Registry (ATSDR), 1988, Toxicological Profile for Beryllium, prepared by the Syracuse Research Corporation for Agency for Toxic Substances and Disease Registry, ATSDR/TP-88/07, Dec.

Foley, R.D., et al., 1992a, Radiological Survey Results foi the Peek Street Site Properties, Schenectady, New York, ORNL-6623, Measuriment Applications and Development Group, Oak Ridge National Laboratory, Oak Ridge, Tern.

Foley, R.D., et al., 1992b, Results of the Radiological Survey at the Sacandaga Site, Glenville, New York, ORNL-6638, Measurement Applications and Development Group, Oak Ridge National Laturatory, Oak Ridge, Tenn.

Ng, Y.C., ei al., 1968, Prediction of the Maximum Dosage to Man from the Fallout of Nuclear Devi:es, in Handbook for Estimating the Maximum Internal Dose from Radionuclides Released to the Biosphere, Lawrence Livermore Radiation Laboratory, University of California, Livermore, Calif.

Paustenbach, D.J., 1989, A Comprehensive Methodology for Assessing the Risks to Humans and Wildlife Posed by Cnntaminated Soils: A Case Study Involving Dioxin, in The Risk Assessment of Environmental and Hum: n Health Hazards: A Textbook of Case Studies, D.J. Paustenbach, ed., John Wiley and Sons, New York.

Shacklette, H.T., and J.G. Boerngen, 1984, Element Concentrations in Soils and Other Surficial Materials of the Conterminous United States, U.S. Geological Survey Professional Paper 1270, Washington, D.C.

U.S. Department of Energy, 1991, Proposed Industrial Hygiene Standard for Beryllium (draft), as forwarded by memo from C.R. Jones (Director, Office of Health Physics and Industrial Hygiene, U.S. Department of Energy, Washington, D.C.) to J.J. Mangeno (U.S. Department of Energy), June 20.

U.S. Department of Labor, 1991, Air Contaminants, Permissible Exposure Limits (29 CFR 1910.1000), Occupational Safety and Health Administration, Washington, D.C.

U.S. Environmental Protection Agency (EPA), 1987, Health Assessment Document for Beryllium, EPA/600/8-84/026F, Office of Health ind Environmental Assessment, Washington, D.C., Nov.

U.S. Environmental Protection Agency (EPA), 1989, Risk Assessment Guidance for Superfund, Volume 1: Human Health Evaluation Manual (Part A-Interim Final), EPA/540/1-89/002, Office of Emergency and Remedial Response, Washington, D.C., Dec. 
U.S. Environmental Protection Agency (EPA), 1990, National Oil and Hazardous Substances Pollution Contingency Plan: Final Rule" (400 CFR 300), Federal Register, 55(35):6154-6176, Fcb. 21.

U.S. Environmental Protection Agency (EPA), 1991a, Human Health Evaluation Manual, Supplemental Guidance: "Standard Default Exposure Factors," memo from T. Fields, Jr. (Acting Director, Office of Emergency and Remedial Response) and B. Diamond (Office of Waste Programs Enforcement), to Director, Various Divisions, Regions I through IX, OSWER Directive 9285.6-03, Office of Solid Waste and Emergency Response, Washington, D.C., March 25.

U.S. Environmental Protection Agency (EPA), 1991b, Integrated Risk Information System, database, Office of Research and Development (accessed in July). 


\section{APPENDIX:}

\section{EQUATIONS AND PARAMETER VALUES}

The equations used for the calculation of beryllium soil and indoor surface concentrations that correspond to given reference values are derived from equations given in U.S. Environmental Protection Agency guidance (EPA 1989). Parameter values used in the equaiions are default values for residential and employee scenarios established by the EPA (1991a). The reference duse and slope factors used are taken from the EPA's Integrated Risk Information System (IRIS) (1991b); the derivation of an inhalation reference limit applicable for the general public and based on the Occupational Safety and Health Administration's standard for permissible occupational 8-hour average exposure (U.S. Department of Labor 1991) is given below.

\section{A.1 Derivation of Inhalation Reference Level Based on Permissible Exposure Limit}

$$
\mathrm{AL}_{\mathrm{w}}=\mathrm{L} \times \mathrm{IR} \times \mathrm{ET} \times \mathrm{EF}
$$

where:

$$
\begin{aligned}
\mathrm{AL}_{\mathrm{w}} & =\text { annual exposure limit for worker }(3,320 \mu \mathrm{g} / \mathrm{yr}), \\
\mathrm{L} & =\text { 8-hour average exposure limit for worker }\left(2 \mathrm{ug} / \mathrm{m}^{3}\right), \\
\mathrm{IR} & =\text { inhalation rate for worker }\left(0.83 \mathrm{~m}^{3} / \mathrm{h}\right), \\
\mathrm{ET} & =\text { exposure time for worker }(8 \mathrm{~h} / \mathrm{d}), \text { and } \\
\mathrm{EF} & =\text { exposure frequency for worker }(250 \mathrm{~d} / \mathrm{yr}) .
\end{aligned}
$$

Further:

$$
\mathrm{RL}_{\mathrm{w}}=\mathrm{AL}_{\mathrm{w}} /(\mathrm{CF} \times \mathrm{EF} \times \mathrm{BW})
$$

where:

$$
\begin{aligned}
\mathrm{RL}_{\mathrm{w}} & =\text { allowable inhalation exposure level for worker }\left(1.3 \times 10^{-4} \mathrm{mg} / \mathrm{kg} / \mathrm{d}\right), \\
\mathrm{CF} & =\text { conversion factor }(1,000 \mathrm{ug} / \mathrm{mg}), \\
\mathrm{EF} & =\text { chronic exposure frequency }(365 \mathrm{~d} / \mathrm{yr}), \text { and } \\
\mathrm{BW} & =\text { body weight }(70 \mathrm{~kg}) .
\end{aligned}
$$


Then:

$$
\mathrm{RL}_{\mathrm{g}}=\mathrm{RL}_{\mathrm{w}} / \mathrm{UF}
$$

where:

$$
\begin{aligned}
\mathrm{RL}_{\mathrm{g}}= & \text { inhalation reference limit for general public }\left(1.3 \times 10^{-5} \mathrm{mg} / \mathrm{kg} / \mathrm{d}\right), \\
& \text { and }
\end{aligned}
$$

For the average air concentration

$$
\mathrm{AL}_{\mathrm{g}}=\left(\mathrm{RL}_{\mathrm{g}} / \mathrm{IR}\right) \times(\mathrm{BW} \times \mathrm{CF})
$$

where:

$$
\begin{aligned}
\mathrm{AL}_{\mathrm{g}} & =\text { average air concentration limit for general public }\left(0.045 \mu \mathrm{g} / \mathrm{m}^{3}\right) \\
\mathrm{IR} & =\text { inhalation rate }\left(20 \mathrm{~m}^{3} / \mathrm{d}\right) \\
\mathrm{BW} & =\text { body weight }(70 \mathrm{~kg}), \text { and } \\
\mathrm{CF} & =\text { conversion factor }(1,000 \mathrm{ug} / \mathrm{mg})
\end{aligned}
$$

\section{A.2 Equation and Parameter Values for the Calculation of Soil Reference Levels for the Incidental Soil Ingestion Exposure Route}

$$
\mathrm{C}=\mathrm{RL} /\left[\left(\mathrm{IR}_{1} \times \mathrm{EF} \times \mathrm{ED}_{1}\right) /\left(\mathrm{BW}_{1} \times \mathrm{AT}\right)+\left(\mathrm{IR}_{2} \times \mathrm{EF} \times \mathrm{ED}_{2}\right) /\left(\mathrm{BW}_{2} \times \mathrm{AT}\right)\right]
$$

where:

$$
\begin{aligned}
& \mathrm{C}=\text { beryllium soil concentration corresponding to given reference level } \\
& (\mathrm{mg} / \mathrm{kg}) \text {; }
\end{aligned}
$$


$\mathrm{ED}_{2}=6$ yr for a child;

$\mathrm{BW}=$ body weight, $\mathrm{BW}_{1}=70 \mathrm{~kg}$ for an adult;

$\mathrm{BW}_{2}=15 \mathrm{~kg}$ for a child 1 to $6 \mathrm{yr}$ old; and

$\mathrm{AT}=$ averaging time, equal to $365 \mathrm{~d} / \mathrm{yr} \times \mathrm{ED}$ for noncarcinogenic effects, equal to $365 \mathrm{~d} / \mathrm{yr} \times 70 \mathrm{yr}$ for carcinogenic effects.

A.3 Equation and Parameter Values for the Calculation of Soil Reference Levels for the Ingestion of Homegrown Produce Exposure Route

$$
\mathrm{C}=[\mathrm{RL} /((\mathrm{IR} \times \mathrm{FI} \times \mathrm{EF} \times \mathrm{ED}) /(\mathrm{BW} \times \mathrm{AT}))] / \mathrm{TF}
$$

where:

$$
\begin{aligned}
\mathrm{C}= & \begin{array}{l}
\text { beryllium soil concentration corresponding to given reference level } \\
(\mathrm{mg} / \mathrm{kg}) ;
\end{array} \\
\mathrm{RL}= & \begin{array}{l}
\text { reference level, equal to } \mathrm{RfD} \text { for beryllium }(0.005 \mathrm{mg} / \mathrm{kg} / \mathrm{d}) \text { for } \\
\text { noncarcinogenic effects; to calculate reference level for carcinogens, } \\
\text { the given risk level }\left(\mathrm{e.g} ., 10^{-4} \text { or } 10^{-6}\right) \text { is divided by the oral slope } \\
\text { factor for beryllium }\left[4.3(\mathrm{mg} / \mathrm{kg} / \mathrm{d})^{-1}\right] ;
\end{array} \\
\mathrm{IR} \mathrm{=} & \text { ingestion rate }(0.2 \mathrm{~kg} / \mathrm{d}) ; \\
\mathrm{FI}= & \text { fraction ingested from contaminated source }(0.4) ; \\
\mathrm{EF}= & \text { exposure frequency }(350 \mathrm{~d} / \mathrm{yr}) ; \\
\mathrm{ED}= & \text { exposure duration }(30 \mathrm{yr}) ; \\
\mathrm{BW}= & \text { body weight }(70 \mathrm{~kg}) ; \\
\mathrm{AT}= & \text { avei ag.ng time, equal to } 365 \mathrm{~d} / \mathrm{yr} \times \text { ED for noncarcinogenic effects, } \\
& \text { equal to } 365 \mathrm{~d} / \mathrm{yr} \times 70 \mathrm{yr} \text { for carcinogenic effects; and } \\
\mathrm{TF}= & \text { soil-to-plant transfer factor for beryllium }(0.00042) .
\end{aligned}
$$

\section{A.4 Equation and Parameter Values for the Calculation of Soil Reference Levels for the Inhalation of Resuspended Particulates Exposure Route}

$$
\mathrm{C}=[\mathrm{RL} /((\mathrm{IR} \times \mathrm{ET} \times \mathrm{EF} \times \mathrm{ED}) /(\mathrm{BW} \times \mathrm{AT}))] \times \mathrm{CF} /(\mathrm{PC} \times \mathrm{FR})
$$


where:

$\mathrm{C}=$ beryllium soil concentration corresponding to given reference level $(\mathrm{mg} / \mathrm{kg})$;

$\mathrm{RL}=$ reference level $(\mathrm{mg} / \mathrm{kg} / \mathrm{d})$, equal to reference limit for the general public based on modified permissible exposure limit (PEL) for beryllium (i.e., $1.3 \times 10^{-5} \mathrm{mg} / \mathrm{kg} / \mathrm{d}$; see Section A.1) for noncarcinogenic effects; to calculate reference level for carcinogens, the given risk level (e.g., $10^{-4}$ or $10^{-6}$ ) is divided by the inhalation slope factor for beryllium $\left[8.4(\mathrm{mg} / \mathrm{kg} / \mathrm{d})^{-1}\right]$

$I R=$ inhalation rate $\left(0.83 \mathrm{~m}^{3} / \mathrm{h}\right)$;

$\mathrm{ET}=$ exposure time $(24 \mathrm{~h} / \mathrm{d})$

$\mathrm{EF}=$ exposure frequency $(350 \mathrm{~d} / \mathrm{yr})$

$\mathrm{ED}=$ exposure duration $(30 \mathrm{yr}) ;$

$\mathrm{BW}=$ body weight $(70 \mathrm{~kg})$;

$\mathrm{AT}=$ averaging time, equal to $365 \mathrm{~d} / \mathrm{yr} \times \mathrm{ED}$ for noncarcinogenic effects, equal to $365 \mathrm{~d} / \mathrm{yr} \times 70 \mathrm{yr}$ for carcinogenic effects;

$\mathrm{CF}=$ conversion factor $\left(10^{6} \mathrm{mg} / \mathrm{kg}\right)$;

$\mathrm{PC}=$ air particulate concentration $\left(0.15 \mathrm{mg} / \mathrm{m}^{3}\right) ;$ and

$\mathrm{FR}=$ fraction of air particulate concentration that is respirable (0.5).

A.5 Equation and Parameter Values for the Calculation of Indoor Surface Reference Levels for the Inhalation of Resuspended Dust Exposure Route

$$
\mathrm{C}=[\mathrm{RL} /((\mathrm{IR} \times \mathrm{ET} \times \mathrm{EF} \times \mathrm{ED}) /(\mathrm{BW} \times \mathrm{AT}))] \times \mathrm{CF} /(\mathrm{PC} \times \mathrm{FR})
$$

where:

$\mathrm{C}=$ beryllium surface concentration corresponding to given reference level $(\mathrm{mg} / \mathrm{kg})$;

$\mathrm{RL}=$ reference level $(\mathrm{mg} / \mathrm{kg} / \mathrm{d})$, equal to reference limit for the general public based on modified PEL for beryllium (i.e., $1.3 \times 10^{-5}$ $\mathrm{mg} / \mathrm{kg} / \mathrm{d}$; see Section A.1) for noncarcinogenic effects; to calculate reference level for carcinogens, the given risk level (e.g., $10^{-4}$ or $10^{-6}$ ) is divided by the inhalation slope factor for beryllium $\left[8.4(\mathrm{mg} / \mathrm{kg} / \mathrm{d})^{-1}\right]$; 


$$
\begin{aligned}
& \mathrm{IR}=\text { inhalation rate }\left(0.83 \mathrm{~m}^{3} / \mathrm{h}\right) \\
& \mathrm{ET}=\text { exposure time }(8 \mathrm{~h} / \mathrm{d}) \\
& \mathrm{EF}=\text { exposure frequency }(250 \mathrm{~d} / \mathrm{yr}) \\
& \mathrm{ED}=\text { exposure duration }(25 \mathrm{yr}) \\
& \mathrm{BW}=\text { body weight }(70 \mathrm{~kg}) ; \\
& \mathrm{AT}=\text { averaging time, equal to } 365 \mathrm{~d} / \mathrm{yr} \times \mathrm{ED} \text { for noncarcinogenic effects, } \\
& \mathrm{CF}=\text { conversion factor }\left(10^{6} \mathrm{mg} / \mathrm{kg}\right) ; \\
& \mathrm{PC}=\text { air particulate concentration }\left(2 \mathrm{mg} / \mathrm{m}^{3}\right) ; \text { and } \\
& \mathrm{FR}=\text { fraction of air particulate concentration that is respirable }(0.5) .
\end{aligned}
$$

\section{A.6 Appendix References}

U.S. Department of Labor, 1991, Air Contaminants, Permissible Exposure Limits (29 CFR 1910.1000), Occupational Safety and Health Administration, Washington, D.C.

U.S. Environmental Protection Agency (EPA), 1989, Risk Assessment Guidance for Superfund, Volume 1: Human Health Evaluation Manual (Part A-Interim Final), EPA/540/1-89/002, Office of Emergency and Remedial Response, Washington, D.C., Dec.

U.S. Environmental Protection Agency (EPA), 1991a, Human Health Evaluation Manual, Supplemental Guidance: "Standard Default Exposure Factors," memo from T. Fields, Jr. (Acting Director, Office of Emergency and Remedial Response) and B. Diamond (Office of Waste Programs Enforcement), to Director, Various Divisions, Regions I through IX, OSWER Directive 9285.6-03, Office of Solid Waste and Emergency Response, Washington, D.C., March 25.

U.S. Environmental Protection Agency, 1991b, Integrated Risk Information System, database, Office of Research and Development (accessed in July). 

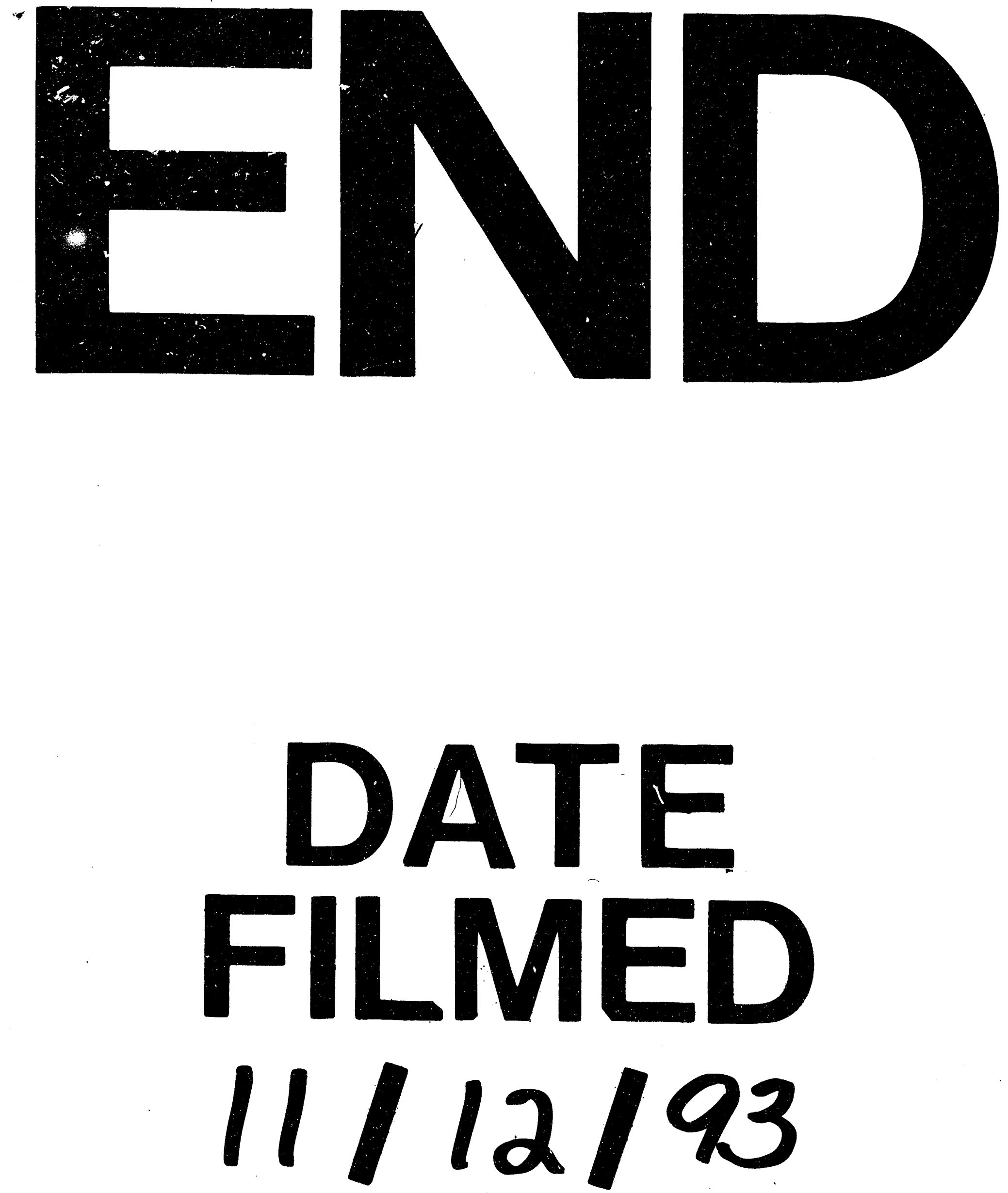
